\section{Tonje Mellin-Olsen}

Enhetsleder, Klinisk støtte

Lovisenberg Diakonale Sykehus

Foto: Lovisenberg Diakonale Sykehus

\title{
Vi blir bedre sammen!
}

Det er tøft for alle faggruppene i helsevesenet å jobbe over tid med begrensede ressurser, under sterkt press, i møte med sykdom og lidelse - men jobber vi sammen, er vi mindre alene.

«Geir» er en enslig mann som legges inn med akutt forverring av kronisk leversvikt. Han sluttet å drikke for en tid tilbake, men har permanent leverskade med cirrhose. Han innkommer ekstremt mager og med stor buk. Han er helt utmattet, og det er så vidt han klarer å stå oppreist. Han har spist minimalt de siste ukene og hoster og svelger vrangt når han prøver å spise. I munnen hans er det rotrester etter manglende tennerhan kan ikke huske sist han var hos tannlegen. Han plages av dødsangst og uro.

Behandlingsplan: Starte opp symptombehandling, medisinskernæringsbehandling og tappe for ascites. Utredning for eventuell levertransplantasjon startes. Men hva med alt det andre? Hvordan få bukt med underernæringen over tid? Hva vil hans svelgfunksjon og tannproblemer ha å si for matinntaket? Hvordan ruste ham til en eventuell transplantasjon? Hvem ser på mobilisering og kartlegger funksjon og hjemmeforhold? Hvordan hjelpe ham med hans angst og uro?

Den fiktive, men typiske pasienthistorien ovenfor illustrerer hvordan klinisk ernæringsfysiolog, logoped, tannlege, ergoterapeut, fysioterapeut og sosionom er gode og helt nødvendige ressurser $\mathrm{i}$ et medisinsk, tverrfaglig team for å få behandlet pasienten adekvat. Tverrfaglig samarbeid handler om å anerkjenne og verdsette at vi alle innehar hver vår spisskompetanse: Fra ulike stå- steder bidrar vi med avgjørende innsikt i vurderingen av hvilke tiltak som er mulige, evidensbaserte, trygge, helhetlige, kloke, koordinerte, relevante og gjennomførbare for pasienten.

Men det handler også om å ta inn over oss at vi er vanlige, ufullkomne og feilbarlige mennesker, som ikke alltid klarer å gjenkjenne eller få med oss alle tegn og detaljer i pasientens sykdomsbilde og livs situasjon. Sammen kan vi skape en bedre arbeidshverdag ved å definere felles mål, fordele ansvar, avlaste hverandre og heie på hverandre. Sammen kan vi forbedre behandlingsresultatet og fremme pasientsikkerheten ved å lære av og lytte til hverandre.

Men vi erfarer noen sentrale hindre. Ett av dem er at man ofte har en stereotypisk oppfatning av andre faggrupper, som hindrer riktig etterspørsel og bruk av kompetansen. Reelt tverrfaglig samarbeid krever derfor tilstedeværelse. Det er gjennom felles opplevelser at vi blir kjent, forstår hverandre, og lærer å utnytte hverandres kompetanse optimalt.

Et annet hinder er at det stilles spørsmål om det er nødvendig med alle faggruppene når pasienten ligger inne på sykehuset så kort tid. Svaret er selvfølgelig at nettopp den korte liggetiden stiller et ekstra stort krav til rask, tverrfaglig kartlegging, utredning, behandling, ernæring og mobilisering, for å klare å snu en akutt og kritisk utvikling i løpet av den begrensede tiden som er til rådighet.

Et tredje hinder er legenes arbeidshverdag. Fremdeles kan jeg høre leger si at de ikke har tid til tverrfaglig samarbeid. Utsagnet underbygger at det er et ledelsesansvar å oppmuntre, støtte og tilrettelegge for tverrfaglig samarbeid. Settes det av tid i legenes timeplaner til å delta i tverrfaglige møter der man kan diskutere status, alternative tilnærminger og videre tiltak? Sørges det for at legene kan delta i arbeidsgrupper? Brukes det tverrfaglige teamet systematisk i opplæringsprogrammer for nyansatte leger? Er det definert hvilke faggrupper som skal inn på hvilke tidspunkt i behandlingsforløpene?

Hva med primærhelsetjenesten? Mye av den nevnte spisskompetansen er ujevnt fordelt eller endog fraværende i primærhelsetjenesten. Vil politikere og ledere sørge for at de kommende primærhelseteamene inkluderer nødvendig, tverrfaglig kompetanse, og at vi får smarte finansieringsordninger som belønner teamarbeid? I et ideelt pasientforløp treffer jeg «Geir» igjen ett år senere:

«Geir» er helt ugjenkjennelig. Han har fått ny lever, nytt bosted, deltidsjobb og nye og edru venner. Han har lagt på seg flere kg og går selv uten rullator eller stokk. Han har til og med begynt å trene på frisklivssentralen. Han er blid og positiv med en helt ny gnist iblikket.

Jeg oppfordrer hver enkelt lege til å være veldig mye tydeligere på at dere trenger bidrag fra andre faggrupper. Ta kontakt med oss: En samtale er undervurdert! Fortsett å etterspørre oss der vi fremdeles mangler.

Gode tverrfaglige team er en kritisk suksessfaktor for å nå målet om effektive og sikre helsetjenester av høy kvalitet. Blir du med på laget?

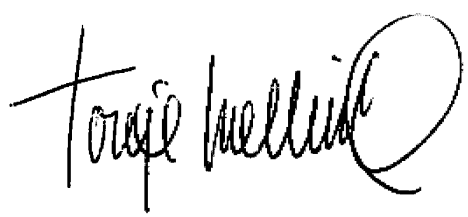

